\title{
Food Composition and Feeding Habits of the Roe Deer in Winter in Central Finland
}

\author{
Pekka HELLE ${ }^{1}$
}

Helle P., 1980: Food composition and feeding habits of the roe deer in winter in central Finland. Acta theriol., 25, 32: 395-402 [With 3 Tables \& 1 Fig.].

The food composition and feeding habits of the roe deer (Capreolus capreolus Linnaeus, 1758) were studied from October to April in the winters of $1975 / 76$ and $1976 / 77$ at Muhos in Finland (ca. $65^{\circ} \mathrm{N}, 26^{\circ} \mathrm{E}$ ). The food composition was determined microscopically from pellets and by tracing tracks of the roe deer in the snow. Vaccinium vitis-idaea, Betula sp., Populus tremula and Parmelia physodes were the most commonly eaten plant species. About $30 \%$ of the food was dug up from under or inside the snow during the period of deepest snow in December-April. The roe deer consumed considerable amounts of arboreal lichens, but barking was not observed. The most favoured winter habitats were Picea forests and river valleys, the areas with the thinnest snow cover locally. Reduced snow cover, shelter and an adequate food supply are the main factors in winter habitat selection for the roe deer in the northern parts of its distribution range.

[Dept. Zool., Univ, Oulu, Kasarmintie 8, SF-90100, Oulu 10, Finland].

\section{INTRODUCTION}

Changes in the distribution of the roe deer (Capreolus capreolus) during recent centuries are well documented in Fennoscandia (see e.g., Ekman, 1922; Olstad, 1944; Ka lela, 1948; Curry-Lindah1, 1967). The species inhabited northern Fennoscandia at earlier times, but disappeared during the eighteenth century due to the deterioration in the climate ( $\mathrm{K}$ a l e l a, 1948). In the present century it has again begun to spread into Finland, and the country nowadays possesses a small resident population ( $\mathrm{Pu}$ lli a in e $\mathrm{n}, 1977,1980 ; \mathrm{H} \mathrm{ell} \mathrm{e,} \mathrm{1978).} \mathrm{The}$ distribution area in Fennoscandia stretches as far as latitude $67^{\circ}$ th $\mathrm{N}$ (Fig. 1), and wandering specimens have been observed even on the coast of the Arctic Sea (Pulliainen, 1980). Winter is the critical season in the marginal areas, with a critical snow depth for the species of about $50 \mathrm{~cm}$ (F or mos ov, 1946). The purpose of the work reported here was to study the roe deer under these extreme circumstances, and

1 Present address: Oulanka Biological Station, University of Oulu, Torikatu 7, SF-90100 Oulu 10, Finland. 
to ascertain how it manages to overcome the considerable difficulties it experiences in hard winters.

\section{STUDY AREA AND METHODS}

The study was carried out at Muhos on the river Oulujoki in central Finland $\left(64^{\circ} 45^{\prime} \mathrm{N}, 26^{\circ} 11^{\prime} \mathrm{E}\right.$, Fig. 1). The area is predominantly coniferous forests, with occasional mires, some cultivated fields and a number of river valleys some $10-20 \mathrm{~m}$ in depth and with a rich vegetation. The forests close to these valleys are moist, with a tree cover of Picea abies and Pinus sylvestris.

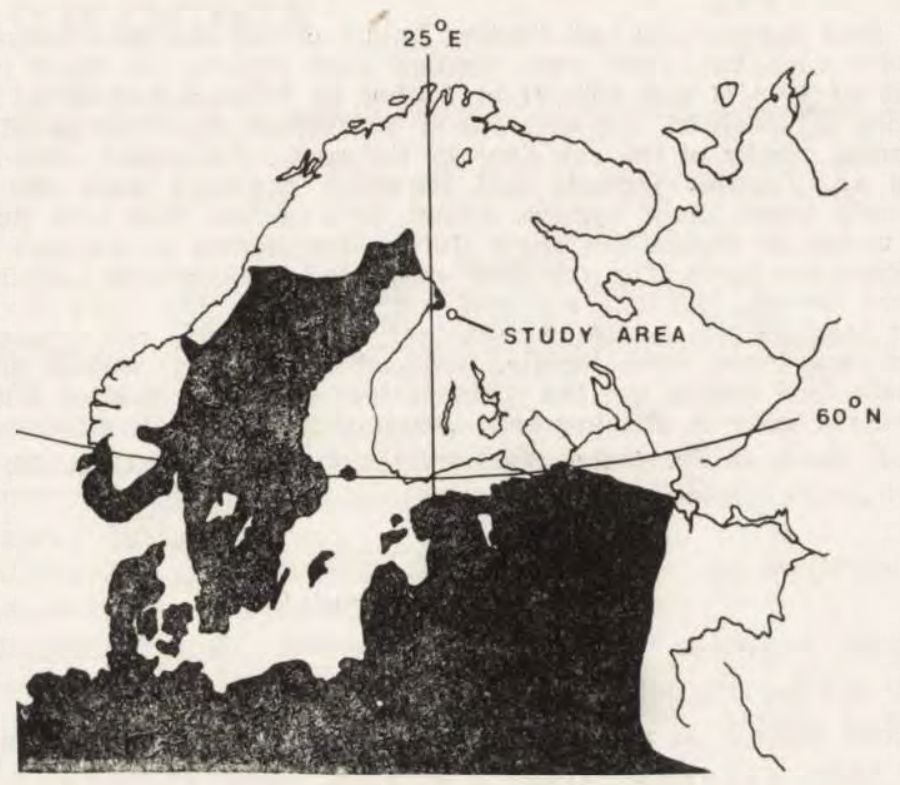

Fig. 1. The distribution of the roe deer in northern Europe according to van den Brink (1967), Siivonen, (1977) and Pulliainen (1980) and the location of the study area.

The monthly mean temperatures in the study area and the average depth of the snow cover on the 15th of each month are as follows (mean 1911-60, Anon. 1975-77):

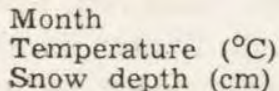

$$
\begin{array}{rrrrrr}
\text { XI } & \text { XII } & \text { I } & \text { II } & \text { III } & \text { IV } \\
-2 & -6 & -9 & -10 & -7 & 0 \\
7 & 15 & 30 & 45 & 47 & 32
\end{array}
$$

The present roe deer population in Muhos is one of the northernmost regular ones in Finland. The first individuals were observed in 1963, and the population reached its peak to date, 32 specimens, in 1971. We are thus dealing with a minute and very remote population located almost $200 \mathrm{~km}$ away from the limit of the constant range of the species in northwest Finland (Fig. 1). 
Field studies were performed twice a month in October-April during the winters of $1975 / 76$ and $1976 / 77$, the main study area (200 ha) being devided into five parts for the purpose of studying the preference order of the winter habitats. (1) Previously grazed meadows $(20 \mathrm{ha})$ close to the rivers, rich in bushes of Salix and Betula and with Carex, Festuca and Agrostis species dominant in the field layer, (2) river valleys ( $45 \mathrm{ha})$ with a dense shrub layer of Betula spp., Populus tremula, Prunus padus and Ribes nigrum and mature forest of Pinus, Picea and Populus, (3) Picea forests (40 ha) with Picea and Pinus regeneration located near the river valleys, (4) mature Pinus forests ( 80 ha) with Vaccinum vitis-idaea and Calluna vulgaris dominant in the field layer, and (5) clearings in Picea forests (15 ha) which have been felled five years earlier and had a well-developed carpet of Deschampsia flexuosa.

The thickness of the snow cover was measured systematically in each sub-area $(1-5)$, especially in river valleys (48 observation points).

Microscopic cuticula analyses were made from fresh pellets (method as in Dusi, 1949 and Hegg, 1961). Six plant groups were distinguished: (1) arboreal lichens, (2) herbs, (3) deciduous trees and shrubs, (4) dwarf shrubs, (5) grasses and sedges and (6) other plants. The total material consisted of 77 pellet groups, implying identification of 7700 cuticula particles. The composition of the winter food was examined further by following tracks of the roe deer in the snow and counting all sufficiently fresh evidence of grazing or digging (see $\mathrm{Nasimovich}$ 1958). Three categories of feeding were recognized: (1) trees from which the roe deer had eaten lichens, (2) twigs of deciduous trees and shrubs and (3) digging in the snow. The material obtained comprises 430 feeding events. The pellet and tracking analyses were combined as follows: if deciduous trees formed e.g., $30 \%$ of all plant particles in the pellet analysis and roe deer had eaten Betula, Populus and Prunus in the proportions $3: 2: 1$, then these trees were regarded as making up 15,10 and $5 \%$ of the diet respectively.

\section{RESULTS}

\section{Winter Food and Habitats}

The composition of the winter food of the roe deer is determined by combining the results of the pellet and tracking analyses (Table 1). The most important trees and shrubs were Betula spp., Populus tremula and Ribes nigrum. Vaccinium vitis-idaea and V. myrtillus were the most eaten dwarf shrubs and Parmelia physodes the major arboreal lichen consumed. Altogether 17 plant species were observed in the diet. During the winter months with a heavy snow cover arboreal lichens and deciduous trees and shrubs are available above snow, while the rest must be dug for under or inside the snow. The percentage of the food obtained in the latter manner is depicted in the tabulation:

$\begin{array}{lrrrrc}\text { Month } & \text { I } & \text { II } & \text { III } & \text { IV } & \text { Mean } \\ 1975 / 76 & 35 & 43 & 30 & 64 & 39 \\ 1976 / 77 & - & 25 & 11 & 65 & 22\end{array}$


Table 1

Percentage food composition of the roe deer in January-April 1976 and 1977 in Muhos, Finland. (See text for further explanation).

\begin{tabular}{lrr}
\hline & 1976 & 1977 \\
\cline { 2 - 3 } Vaccinium vitis-idaea & 21.9 & 11.6 \\
Betula verrucosalpubescens & 10.6 & 16.6 \\
Populus tremula & 8.9 & 13.9 \\
Parmelia physodes & 9.8 & 7.8 \\
Ribes nigrum & 5.5 & 8.6 \\
Vaccinium myrtillus & 9.0 & 4.8 \\
Alnus incana & 4.8 & 7.5 \\
Alectoria sarmentosa & 6.5 & 5.3 \\
Salix phylicifolia & 3.8 & 5.9 \\
Usnea hirta & 2.8 & 2.3 \\
Gyrophora polyphylla & 2.8 & 2.2 \\
Deschampsia caespitosa & 1.7 & 1.0 \\
Parmelia ambiqua & 1.4 & 1.1 \\
Deschampsia flexuosa & 1.5 & 1.0 \\
Empetrum nigrum & 1.3 & 0.7 \\
Prunus padus & 0.7 & 1.1 \\
Physcia hispida & + & + \\
Herbs & 1.5 & 1.5 \\
Others & 5.2 & 7.1 \\
Total & 100.0 & 100.0 \\
\hline
\end{tabular}

Most of the feeding on trees and shrubs took place at less than $70 \mathrm{~cm}$ above the snow level and less than $100 \mathrm{~cm}$ above the ground. The diameters of the twigs which had been broken off varied from 1.5 to $5.5 \mathrm{~mm}$, being most commonly $2.5-3.0 \mathrm{~mm}$. According to the availability of trees and shrubs the tracking studies gave evidence for the following order of preference:

Prunus $>$ Ribes $>$ Alnus $>$ Populus $>$ Salix $>$ Betula .

The areas exposed by digging varied from 6 to $64 \mathrm{dm}^{2}$ (mean $20 \mathrm{dm}^{2}$ ), and the snow depths at these digging sites ranged $7-50 \mathrm{~cm}$,

Table 2

Relative frequency of bedding-sites and pellet groups of the roe deer found in December-April in Muhos, Finland.

\begin{tabular}{lcc}
\hline & $\begin{array}{c}\text { Bedding-sites } \\
\text { per 10 ha }\end{array}$ & $\begin{array}{c}\text { Pellet-groups } \\
\text { per 10 ha }\end{array}$ \\
\hline Picea forests & 2.0 & 7.0 \\
Pinus forests & 0.3 & 0.8 \\
Meadows & 0.5 & 5.0 \\
Clearings in forest & 0 & 4.7 \\
River valleys & 10.0 & 5.8 \\
$\quad$ n & 56 & 77 \\
\hline
\end{tabular}


averaging $22 \mathrm{~cm}$. The plant species most abundantly grazed on in this way were Vaccinium vitis-idaea, V. myrtillus, Deschampsia caespitosa and D. flexuosa.

According to the number of pellet groups found, the most important habitat for the roe deer in December-April was Picea forest, followed by meadows, river valleys and clearings, while the Pinus forests were quite unimportant in this respect (Table 2). The relative abundance of snow tracks in these biotopes confirms this order of preference. Most of the bedding-sites $(75 \%)$ were found in the river valleys (Table 2).

\section{Snow Conditions in the Study Area}

The winters of $1975 / 76$ and $1976 / 77$ were quite normal in respect of their snow depth in late autumn and in spring, but there was more snow than usually in February in both years: $53 \mathrm{~cm}$ in 1976 and $75 \mathrm{~cm}$ in 1977 (mean $45 \mathrm{~cm}$ in 1911-60, Anon. 1975-77). The thinnest snow cover was recorded in the Picea forests, averaging $38 \mathrm{~cm}$ in March, while depths were twice as great in the meadows and clearings (Table 3 ).

Table 3

Snow depths in the study area during the period of most difficult snow conditions. The figures are the means of several measurements.

\begin{tabular}{lcc}
\hline & March, 1976 & March, 1977 \\
\hline Picea forests & 30 & 45 \\
Pinus forests & 42 & 55 \\
Meadows & 57 & 71 \\
Clearings in forest & 59 & 74 \\
River valleys & 62 & 72 \\
Bottom & 28 & 60 \\
North-facing slopes & 52 & 61 \\
East-facing slopes & 11 & 20 \\
South-facing slopes & 25 & 40 \\
West-facing slopes & & \\
\hline
\end{tabular}

The river valleys also had quite a deep snow cover at that time $(53 \mathrm{~cm}$ on average), but the distribution of the snow was very uneven, and it never exceeded $20 \mathrm{~cm}$ in depth on the south-facing slopes (Table 3).

\section{DISCUSSION}

In the northern parts of its range the roe deer eat dwarf shrubs, twigs of trees and shrubs and arboreal lichens in winter (F o r m o s ov, 1946; H a g e n, 1958; M a rkgre n, 1966). Arboreal lichens seem to be 
very important in northern Sweden, and the roe deer are also known to eat them in the Alps (Markgren, 1966). Siivonen (1972) has mentioned that the roe deer seldom takes the bark of fallen aspens, and the present results point to a similar conclusion. The winter food of the roe deer in Poland consists mainly of Pinus, Picea, Betula, Calluna and Fagus (Si uda et al., 1969; B orowski \& Kossak, 1975), and in Britain of Pinus, Calluna and grass-like plants (H e n r y, 1978). There is a considerable difference in the use made of arboreal lichens between the Finnish and middle European roe deer, since these form about $20 \%$ of the diet in Finland but do not appear at all in Poland and Britain. A great difference also emerges in the diversity of the winter food composition in these studies, since the Polish roe deer will accept over 90 plant species (S i u da, et al., 1969) compared with only 17 in Finland and 11 in Britain (H en r y, 1978). B or ow s ki \& Ko s s a k (1975) note that roe deer eat the bark of deciduous trees and Picea in Poland.

The food of the roe deer in Muhos was quite different during the two winters studied (Table 1). This is due to the greater snow depth during the latter winter (Table 3), for when the snow depth is over $50 \mathrm{~cm}$ the roe deer must use food supplies available above the snow level, as is reflected in the higher proportions of trees and shrubs, since it proves impossible to feed on arboreal lichens any more extensively because of the small quantity available. The roe deer didn't visit the hay barns in the nearby fields during the winter, in contrast with the observation of Pulliainen (1977) that these constitute important food sources in the Tornio district, about $150 \mathrm{~km}$ north of Muhos.

The river valleys were important winter habitats for the roe deer in the Muhos area, in spite of the depth of snow encountered in them (Table 2). The uneven distribution of the snow, which depends on wind direction and the density of trees, had left the south-facing slopes with a thinner snow cover, and it is here that most digging events, tracks and bedding-sites were located.

The roe deer overwinters in a variety of habitats in the central parts of its range and the highest densities are found in landscapes with intermingled agricultural land and woodland (e.g., Olstad, 1944; $\mathrm{Siuda}$ et al., 1969). In central Europe there is a special "field ecotype "living its whole life in open areas ( $\mathrm{K}$ a ł u ziński, 1974), but such an ecotype has not been observed in Scandinavia (Hansson, 1979). In more northernly areas the roe deer must choose its winter habitats careful, as the environmental pressure is all the more exacting (Formosov, 1946; Markgren, 1971). Areas with a reduced 
snow cover, shelter and good supplies of food are those which form characteristic winter habitats. In northern Fennoscandia these conditions are realized mainly on river banks (e.g., M a rkgren, 1966), and the spread of the species is also highly dependent on rivers and lakes (E kman, 1922; Pullia in en, 1977, 1980; Helle, 1978). The roe deer does not make long invasions into areas with reduced snow cover in Finland as it does in Russia ( $\mathrm{F}$ or mosov, 1946), and it is similarly very stationary during the winter in Sweden (M a r kgre $\pi$, 1966). In spring, on the other hand, the roe deer begins to wander and the spread of the species is said to be strongly based on this spring migration (P ullia in en, 1980).

Acknowledgements: Prof. Erkki Pulliainen kindly read the manuscript and made suggestions for its improvement. I am also grateful to $\mathrm{Mr}$ Malcolm Hicks, who. checked the English language.

\section{REFERENCES}

1. Anonymous, 1975-77: Monthly reports of the Finnish Meteorological Institute.

2. Borowski S. \& Kossak S., 1975: The food habits of deer in the Bialowieża Primeval Forest. Acta theriol., 20: 463-506.

3. Curry-Lindahl K., 1967: Nordens djurvärld. 463 pp. Stockholm.

4. Dusi J. L., 1949: Methods of determination of food habits by plant microtechniques and histology and their application to Cottontail Rabbit food habits. J. Wildl. Manage., 13: 295-298.

5. Ekman S., 1922: Djurvärldens utbredningshistoria på Skandinaviska halvön. 614 pp. Stockholm.

6. Formosov A. A., 1946: Snow cover as an integral factor of the environment and its importance in the ecology of mammals and birds. (English translation, $176 \mathrm{pp}$. Alberta, 1964).

7. Hagen Y., 1958: Litt om undesøkelser over vinternae ring hos rådyr og elk. - Jeger og Fisker, 87: 1-12.

8. Hansson L., 1979: On the importance of landscape heterogeneity in northern regions for the breeding population densities of homeotherms: a general hypothesis. Oikos, 33: 182-189.

9. Hegg O., 1961: Analysen von Grosswildkot aus den Schweizerischen Nationalpark zur Ermittlung der Nahrungszusammenfassung. Rev. Suisse Zool., 8: 156-165.

10. Helle P., 1978: On the winter ecology of the roe deer, Capreolus capreolus Linné 1758, in northern Finland and its distribution in Fennoscandia. Unpublished M. Sc. Thesis, Department of Zoology, University of Oulu, Oulu, 78 pp. [In Finnish].

11. Henry B. A. M., 1978: Diet of roe deer in an English conifer forest. J. Wildl. Manage., 42: 937-940.

12. Kalela O., 1948:- Metsäkauriin esiintymisestä Suomessa ja sen levinneisyyden muutoksista lähialueilla. [Summary: The occurrence of roe deer 
in Finland and changes in its distribution in the adjoining areas]. Suomen Riista, 3: 34-53.

13. Kaluzinski J., 1974: The occurrence and distribution of field ecotype of roe-dee: in Poland. Acta theriol., 19: 291-300.

14. Markgren G., 1966: Om rådjuren (Capreolus capreolus) in Nordsverige och deras vinterekologi. [Summary: On the winter ecology of the roe deer (Capreolus capreolus) in northern Sweden]. Zool. Revy, 28: 97-107.

15. M a Ikgren G., 1971: De nordliga hjortdjurens vinterproblem - en ekologisk översikt. [Summary: Winter problems of northern cervids - an ecological survey]. Fauna och Flora, 5: 174-186.

16. Na simovich A. A., 1958: Opyt izučenija ekologii mlekopitajuščih putem zimnih troplenij. Zool. Zurnal, 27: 371-378 [In Russian].

17. Olstad O., 1944: Rádyrets (Capreolus capreolus (L.)) utbredelse i Norge. Statens Viltundersøkelser, Meddelelse, 14: 1-63.

18. Pulliainen E., 1977: Comparison of the present land mammal faunas of eastern and western Fennoscandia. Acta Univ. Ouluensis, (in press).

19. Pulliainen E., 1980: Occurrence and spread of the roe deer (Capreolus capreolus L.) in eastern Fennoscandia since 1970. Memoranda Soc. Fauna Flore Fennica, 56: 28-32.

20. S i i 7 on en L., 1972: Suomen nisäkkäät II. - 435 pp. Helsinki.

21. Siizonen L., 1977: Mammals of northern Europe. 196 pp. Helsinki.

22. Siuda A., Zurowski W., \& Siuda H., 1969: The food of the roe-deer. Acta theriol., 14: 247-262.

Accepted, June 20, 1980.

Pekka HELLE

\section{STOSUNKI POKARMOWE U SARNY ZIMA W CENTRALNEJ FINLANDII}

\section{Streszczenie}

Badano skład pokarmu i sposób jego pobierania przez sarny w okresie od październike do kwietnia, w dwóch kolejnych zimach w 1975/76 i 1976/77 w centralnej Finlandii (około $65^{\circ} \mathrm{N} ; 26^{\circ} \mathrm{E}$ ) (Ryc. 1). Pobierano próbki kału i przy pomocy mikroskcpu określano udział poszczególnych roślin zjadanych przez sarnę. Uzupełnieniem tej listy była obserwacja miejsc, w których te zwierzęta wykopywały spod śniegu karmę. Ustalono, że najczęściej zjadanymi gatunkami roślin są: Vacciniun vitis-idaea, Betula sp., Populus tremula i Parmelia physodes (Tabela 1). W okresie od grudnia do kwietnia około $30 \%$ pokarmu jest wykopywane spod śniegu. Sarny zjadają znaczne ilości porostów nadrzewnych lecz nie obserwowano spałowania. Preferowane zimą środowiska to lasy świerkowe i doliny rzeczne czyli tereny z cieńszą okrywą śnieżną (Tabele 2,3). Występowanie cienkiej pokrywy śnieżnej, możliwość łatwego znalezienia schronienia oraz latwy dostęp do odpoviedniego pokarmu to główne czynniki wplywające na zimową selekcję środowiš przez sarnę w północnych częściach jej zasięgu. 